\begin{tabular}{|c|c|}
\hline & $\begin{array}{c}\text { European Association for the } \\
\text { Development of Renewable Energies, } \\
\text { Environment and Power Quality (EA4EPQ) }\end{array}$ \\
(ICREPQ'12) \\
Santiago de Compostela (Spain), 28th to 30th March, 2012
\end{tabular}

\title{
Economic impact of non dispatchable generation on the cost of energy supply and on the adjustment services
}

\author{
Ingrid Oliveros Pantoja ${ }^{1}$ and Máximo López Toledo ${ }^{2}$ \\ ${ }^{1}$ Department of Electrical and Electronical Engineering \\ Universidad del Norte \\ Km 5 via a Pto- Barranquilla-Colombia \\ Phone/Fax number:+0057 53509270,e-mail: inoliver@uninorte.edu.co \\ ${ }^{2}$ Department of Electrical Engineering \\ Escuela Técnica Superior de Ingenieros Industriales \\ C/ José Gutiérrez Abascal, nº 2 - 28006 - Madrid-España \\ Phone/Fax number:+0034 913363175, e-mail: malopez@etsii.upm.es
}

\begin{abstract}
This article presents an analysis of the economic impact of non dispatchable generation on the cost of the energy supply and on the adjustment services and aims to analyze the economic impact of the renewable generation into the Spanish production and adjustment services markets, and thus to help prospective investors in renewable generation projects to analyze the situation of the Spanish electricity market.
\end{abstract}

\section{Keywords}

Adjustment Services, Access Tariff, Feed-in Tariff, Daily Market, Intraday Market

\section{Introduction}

This article presents an analysis of the economic impact of non dispatchable generation on the cost of the energy supply, daily market and on the adjustment services. This analysis is developed in three parts. The first part is an analysis of the current situation in Spain that includes the electricity power demand from 1996 to 2010, how this demand was supplied by the total of energetic sources and the national energy makeup. On this basis we will make a comparative analysis between the evolution of the average monthly price of energy and:

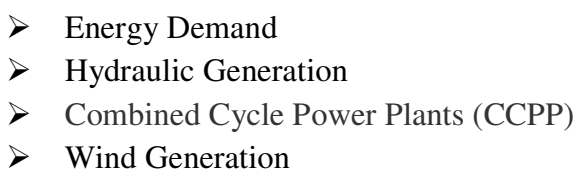

In the second part we discuss the contribution of renewable generation on so-called "access tariff" due to the influence of the feed-in tariff scheme established by
Royal Decree-Law 661/2007. And finally, the third part is developed in two parts in the first one, we review the impact of increasing in $1 \mathrm{GWh}$ of renewable generation into the daily market and in the second one we review the impact of renewable generation in costs associated with adjustment services.

\section{Analysis of the current situation in Spain}

\section{A. Energy Demand}

According to Red Eléctrica de España (REE), the operator of Spain's electricity system [1], the national electricity demand from 1996 to 2010 has grown by $68 \%$. The Figure 1 below shows how this number was derived[2][3].

Fig. 1. Spain electricity demand from 1996 to 2010

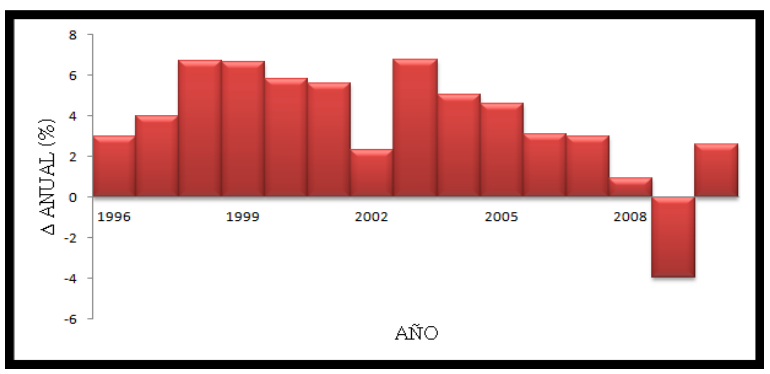

\section{B. National Energy Makeup}

Figure 2 [2], shows the national energy makeup at 2010. The total energy generated in Spain was 288,182 GWh. 
Conventional energy sources (nuclear and fossil fuel based) still dominate (56\%), although there is a trend to increase the participation of renewable energies in the energy makeup and accomplish the 2020 target

Fig. 2. 2010National energy makeup

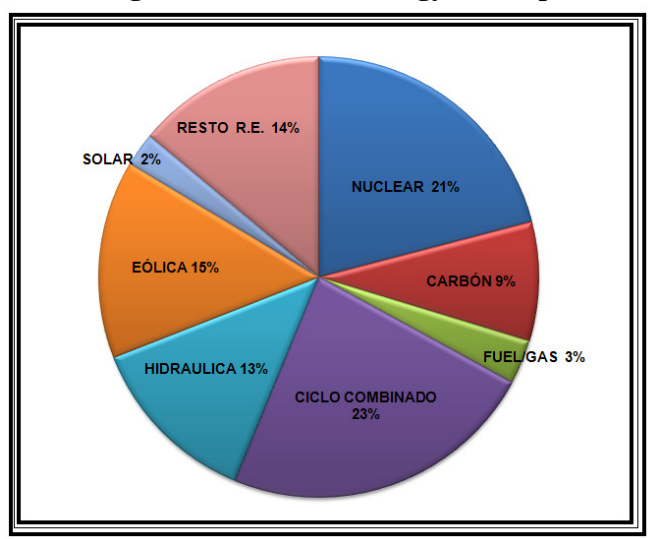

C. Average monthly price of energy and energy demand

The price of electricity in the Spanish electricity market depends on the price of the daily market clearing, the Intraday market clearing price, the price of the system adjustment services (technical constraints and ancillary services) and the cost of capacity payments. Figure 3[3], shows the historical behavior of the average monthly price of electrical energy and the demand for the period between January 2000 and December 2010.

Fig. 3. Historical behavior: average monthly price/demand

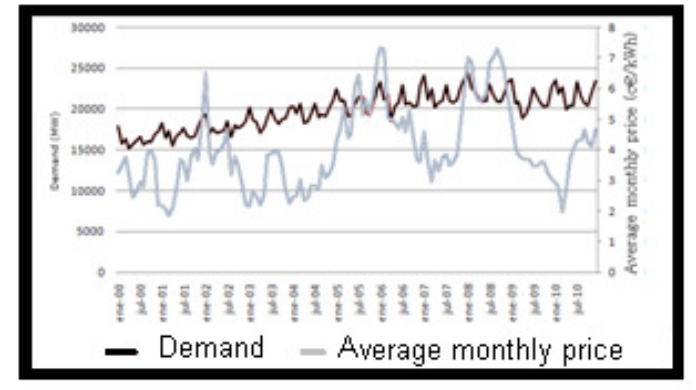

\section{Average monthly price of energy and hydraulic generation}

Coverage of demand is highly dependent on weather conditions due to the high penetration of wind energy and hydropower. Hydro generation technology affects the market price because this generation has a practically zero variable cost. Figure 4 shows the historical behavior of average monthly price of electrical energy and hydro generation between January 2000 and December 2010 [4].
Fig. 4. Historical behavior: average monthly price/Hydro

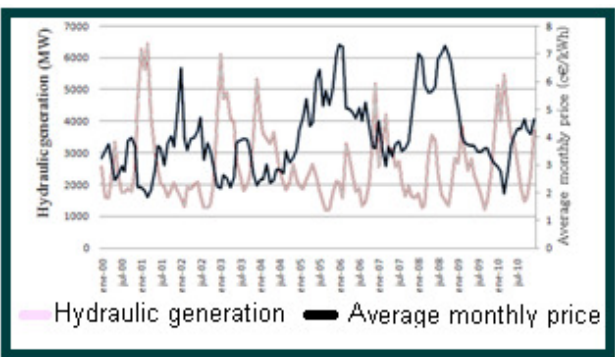

\section{E. Average monthly price of energy and CCPP generation}

The supply of natural gas has becoming a key element for the final electricity production through the combined cycles. In Spain, CCPP began operation in 2003. CCPP normally operate after nuclear, hydro and "special regime" (energy sources that use co-generation, renewable sources and waste products in facilities with rated power of no more than $50 \mathrm{MW}$ ). Generation with CCPP is the most expensive and hence the price trend is proportional to the energy generation by CCPP. The trend of CCPP and hydro generation is reversed because CCPP offsets the hydraulic power that is not generated in the summer; both have a seasonal trend, summer and winter. Figure 5 shows the historical behavior of average monthly price of electrical energy and CCPP generation between January 2003 and December 2010.

Fig. 5. Historical behavior: average monthly price/CCPP

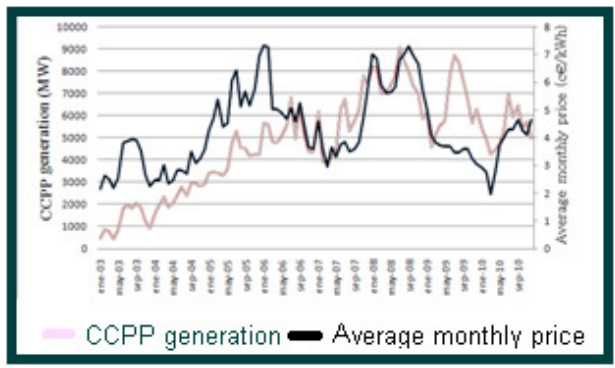

\section{F. Average monthly price of energy and wind generation}

Figure 6, shows the historical behavior of average monthly price of electrical energy and wind generation, from 2003 to 2010 .

Fig. 6. Historical behavior: average monthly price/ wind

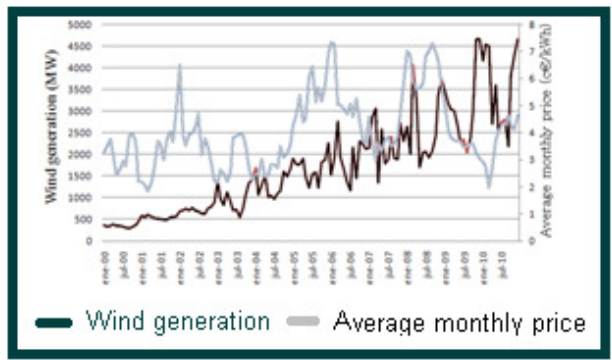




\section{Effect of the feed-in tariff for the renewable generation in the access tariff.}

The access tariff pays for transmission and distribution services, as well as for the permanent costs of the system. This tariff is paid by the client through their Resellers, it is set by the Ministry of Industry, Tourism and Trade, and it can be reviewed quarterly. Figure 7 [5] (Royal Decree 1164/2001, of 26 October [6]), shows the components of the access tariff.

Fig. 7. Components of the Access Tariff

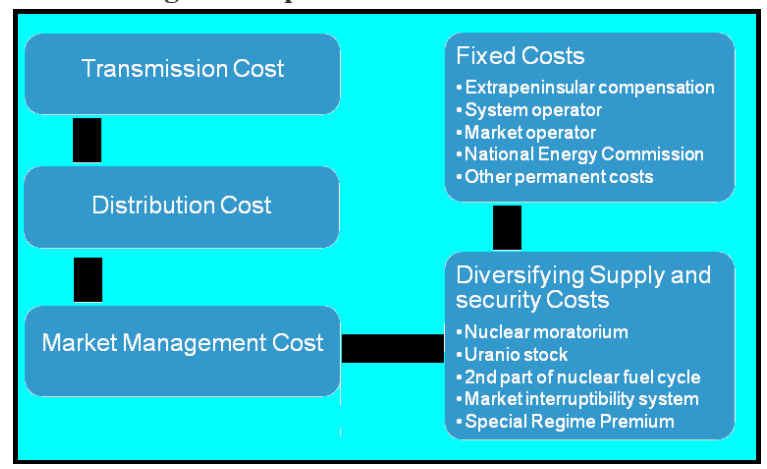

Royal Decree 1164/2001, of 26 October also establishes the structure of the access tariff (figure 8):

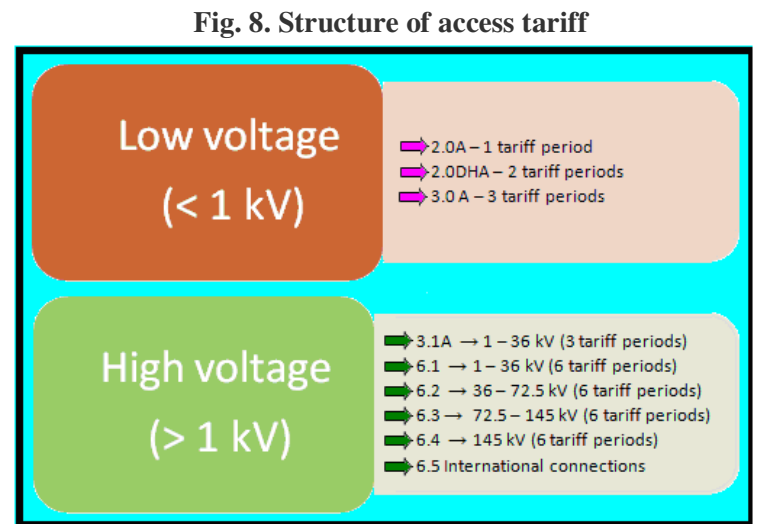

Figures 9, 10 and 11 show the evolution of the access tariff from 2006 to 2010 [7][8][9][10][11][12][13][14] [15]..

Fig. 9. Evolution of the low voltage access tariff from 2006 to 2010

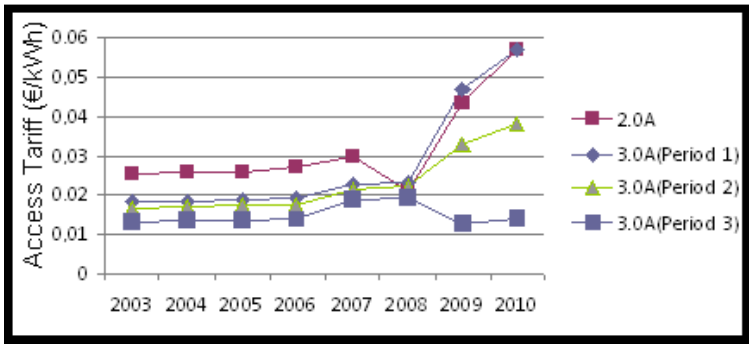

Fig. 10. Evolution of the high voltage (3.1A) access tariff from 2006 to 2010

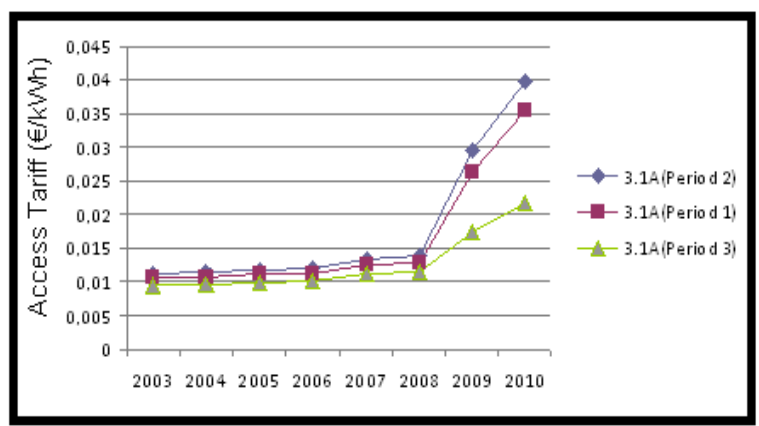

Fig. 10. Evolution of the high voltage $(6.1,6.2,6.3,6.4)$ access tariff from 2006 to 2010

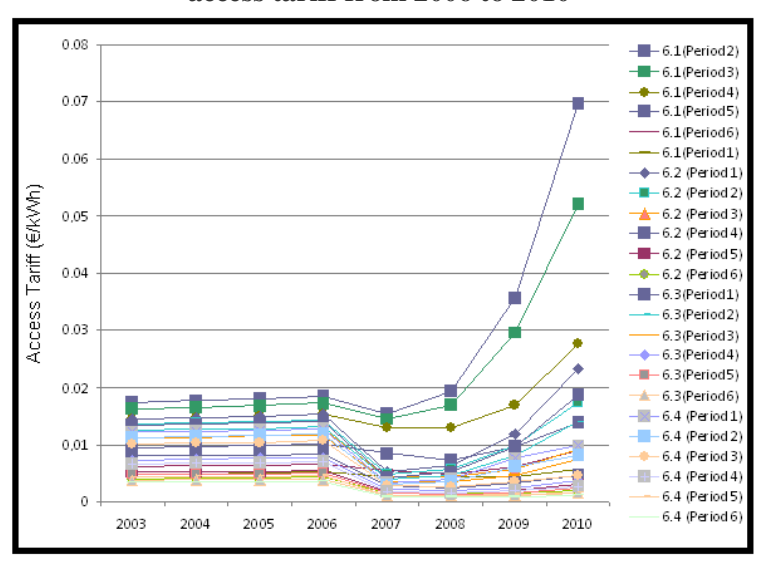

The Royal Decree-Law 661/2007 [16] established the concept of feed in-tariff and fixed upper and lower limits for the market reference price and the reference feed in tariff. Figure 11 shows the behavior of the special regime feed in tariff for the period between January 2003 and December 2011. Since 2007, in Royal Decree-Law $1634 / 2006$ appears offshore wind generation feed in tariff, which triples the average feed in tariff for onshore wind generation.

Fig. 11. Evolution of the feed-in tariff (b.2) from 2003 to 2011

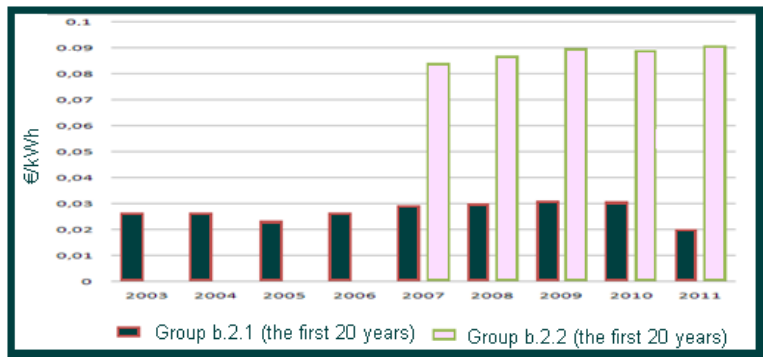




\section{Impact of renewable generation}

\section{A. In daily market}

In Spain the market operator (MO) handle electricity transactions for the following day through the presentation of electricity sale and purchase bids by market participants. The figure 12 [17] shows the supply and the demand curve built by MO with the daily market offers at the first hour on April 19, 2010. The curves show the bid price increasing, in the case of the sales, and decreasing, in the case of the purchases. We get the equilibrium price or the market clearing price (MCP) when the curves meet. As a result of that the quantity supplied and the quantity demanded become equal/the same.

Fig. 12. Daily market offers at the first hour April 19, 2010 Ofinte 19/04/2010 - curras agregadas de oferta y demanda - Hora: 1 - Pais: Espafia

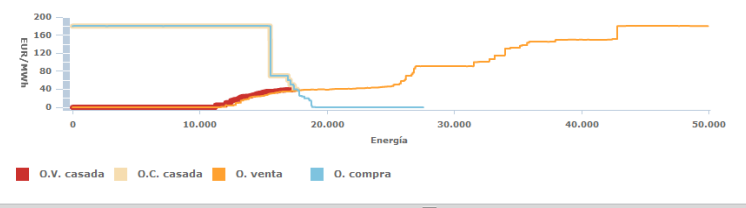

Figure 13 shows the average monthly behaviour of MCP at 2010 without taking on count bids that incorporate complex conditions.

Fig. 13. 2010 MCP monthly behavior $\square € / \mathrm{MWh}$

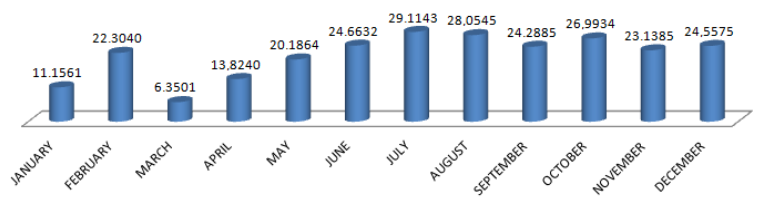

Figure 14 shows the average monthly amount reduction in the pool by adding $1000 \mathrm{MW}$ of renewable generation in every hour. This is due to the fact that renewable energy has a value of zero so that the demand curve is displaced to the right putting the MCP down.

Fig. 14. Total amount reduction in the pool by adding $1000 \mathrm{MW}$ of renewable generation

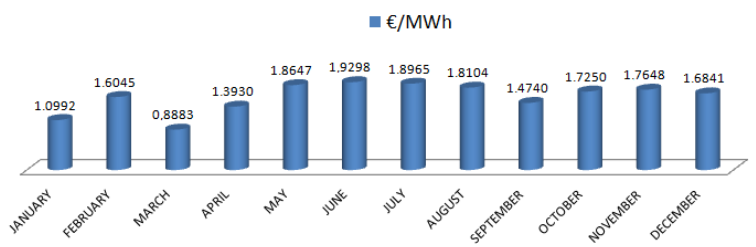

B. In costs associated with adjustment services.

In Spain, adjustment services are managed by REE. In its website [18], the following definition for adjustment services can be found: "Services necessary to ensure the electricity supply under the conditions of quality, reliability and security. The adjustment services can have obligatory or optional character. These are understood as adjustment services such as the resolution of technical restrictions of the system, ancillary services and deviation management".

Adjustment services include: power-frequency regulation (primary, secondary and tertiary), the management of generation deviations and demand, voltage control of the transmission network and service restoration. Figure 15 [3] shows the impact of complementary services in the final energy price from 2003 to 2009.

Fig. 15. Complementary services impact on the final energy

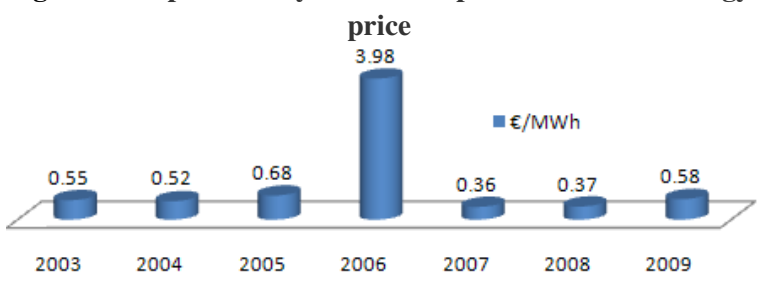

Fig.16 shows the evolution of energy involved in the secondary and tertiary regulation. The deviation management, and the real-time constraints, from 2003 to 2010.

Fig. 16. Evolution of complementary services

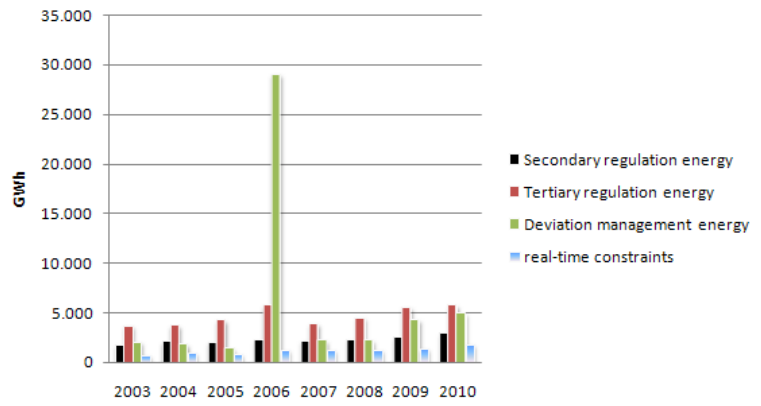

\section{Conclusion}

The electricity demand has grown $68 \%$ onstage 19962010, including moderation suffered by the crisis and recovery since mid-2009.

In Spain the electricity price as in any electricity market in the world depends on the cost of production and technologies that make up the generation park. That is why demand coverage is heavily dependent on atmospheric conditions because of the strong penetration of wind and Hydro generation, as it could be seen in the MCP monthly low averages (result of zero MCP).

An increase of 1000MW of renewable energies, with an almost zero variable costs and priority in the dispatch, result into a decrease in the average price of the daily 
market at $82.20 € \mathrm{MWh}$ which is higher than the price paid by feed-in tarriff of $77.76 € \mathrm{MWh}$ [19]: without application in the access tariff, the cost of the electric fares would be reduced.

\section{References:}

[1] Red Electrica de España. Contribucion de la generacion nuclear en la operacion del sistema electrico Español. 19 de Noviembre de 2010. Disponible en: http://www.upcomillas.es /catedras/crm/descargas/ 2010-011/Carbajo\%2019.11.2010.pdf.

[2] Red Electrica de España. El sistema electrico Español Avance del informe 2010. 21 de Diciembre de 2010. http://www.ree.es/sistema_electrico/pdf/infosis/Avance_REE_2 010.pdf.

[3] Informes del Sistema Electrico de 1995 a 2009. RED ELECTRICA ESPAÑA. 2011. http://www.ree.es/sistema_ electrico/informeSEE.asp.

[4] Operador del Mercado Ibérico (OMI). http://www.omie.es/inicio

[5] Claves para entender los mercados energéticos y sus implicaciones en la Sociedad. Energia y sociedad. http://www energiaysociedad.es/detalle_material_didactico.asp.

[6] REAL DECRETO 1164/2001, de 26 de octubre, por el que se establecen tarifas de acceso a las redes de transporte y distribución de energía eléctrica. BOE 268, 20850. Madrid : 26 de octubre de 2001 .

[7] REAL DECRETO 1164/2001, de 26 de octubre,por el que se establecen tarifas de acceso a las redes de transporte y distribución de energía eléctrica. BOE 268, 20850. Madrid: s.n., 26 de octubre de 2001.

[8] REAL DECRETO 1436/2002, de 27 de diciembre, por el que se establece la tarifa eléctrica para 2003. REAL DECRETO 1436, BOE313. Madrid : s.n., 27 de diciembre de 2002.

[9] REAL DECRETO 1802//2003, de 26 de diciembre, por el que se establece la tarifa eléctrica para 2004. REAL DECRETO 1802, Boe 310. Madrid : s.n., 27 diciembre 2003.

[10] Real Decreto 2392/2004, de 30 de diciembrepor el que se establece la tarifa eléctrica para 2005. Real Decreto 2392, Boe 315. Madrid : s.n., 30 de diciembre de 2004.

[11]. Real Decreto 1556/2005, de 23 de diciembre por el que se establece la tarifa eléctrica para 2006. Real Decreto 1556, Boe 310. Madrid : s.n., 23 de diciembre de 2005.

[12] Real Decreto 1634/2006, de 29 de diciembre, por el que se establece la tarifa eléctrica a partir de 1 de enero de 2007 . Real Decreto 1634, Boe 312. Madrid : s.n., 29 de diciembre 2006.

[13] ORDEN ITC/3860/2007, de 28 de diciembre, por la que se revisan las tarifas eléctricas a partir del 1 de enero de 2008. ORDEN ITC3860, Boe312. Madrid : s.n., 28 de diciembre de 2007.
[14] ORDEN ITC/3801/2008, de 26 de diciembre, por la que se revisan las tarifas eléctricas a partir de 1 de enero de 2009. ORDEN ITC/3801, Boe 315. Madrid : s.n., 26 de diciembre 2008 .

[15] Orden ITC/3519/2009, de 28 de diciembre, por la que se revisan los peajes de acceso a partir de 1 de enero de 2010 y las tarifas y primas de las instalaciones del régimen especial. Orden ITC/3519/2009, Boe 315. Madrid: s.n., 28 de diciembre de 2009.

[16] REAL Decreto 661/2007, de 25 de mayo, por el que se regula la actividad de producción de energía eléctrica en régimen especial. Madrid: s.n., 25 de mayo de 2007.

[17] OMEL . Resultados del mercado. http://www.omie.es/files/ flash/ResultadosMercado.swf

[18] RED ELÉCTRICA DE ESPAÑA . Procedimientos de operación. 28 de Octubre de 2010. http://www.ree.es/operacion/procedimientos_operacion.asp.

[19] CNE. Informe sobre los resultados de la liquidacion provisional $\mathrm{n}^{\circ} 14$ de 2010 y verificaciones practicadas sector electrico. Dirección de inspeccion, liquidaciones y compensaciones. Periodo de facturación: desde el 1 de enero de 2010 al 28 de febrero de 2011. 29 de abril de 2011 